\title{
Penerimaan Sistem Informasi Berbasis Teknologi oleh Karyawan PT. Merry's Tour and Travel Menggunakan Aplikasi Quickbooks
}

\author{
Ni Wayan Desi Riani ${ }^{1}$ \\ Fakultas Ekonomi dan Bisnis \\ Universitas Udayana, Indonesia \\ Email: rianidesi277@gmail.com
}

\author{
Ni Ketut Rasmini² \\ Fakultas Ekonomi dan Bisnis \\ Universitas Udayana, Indonesia
}

\begin{abstract}
ABSTRAK
Penelitian ini dimaksudkan untuk mengetahui bagaimana penerimaan karyawan terhadap sistem aplikasi QuickBooksyang diuji coba oleh PT. Merry's Tour and Travel dengan menggunakan Technology AcceptanceModel (TAM). Penelitian ini menggunakan populasi seluruh manajemen dan karyawan PT. Merry's Tour and Travel. Pengambilan sampel dilakukan dengan menggunakan metode purposive sampling dan diperoleh sampel yang memenuhi kriteria sebanyak 34 orang responden. Metode pengumpulan data menggunakan metode survei dengan kuesioner. Data dianalisis dengan menggunakan Structural Equation Model (SEM) yaitu Partial Least Square (PLS). Berdasarkan hasil analisis ditemukan bahwa variabel top management commitment, selftefficacy, dan perceived usefulness mempengaruhi penerimaan sistem informasi QuickBooks pada karyawan PT. Merry's Tour and Travel. Hal ini mengindikasikan bahwa proses transisi perubahan dari sistem manual ke sistem informasi QuickBooks tidak sepenuhnya dapat dijelaskan oleh Technology Acceptance Model.
\end{abstract}

Kata Kunci: $\quad$ Perceived Ease Of Use; Perceived Usefulness; Attitude Toward Using; Behavioral Intension To Use; Technology Acceptancemodel (TAM).

\section{An Empirical Study on Acceptance of Technology Based Information Systems by Merry's Tour and Travel Employees by Using QuickBooks Aplication System}

\begin{abstract}
This research is intended to find out how the employee acceptance of the QuickBooks application system tested by Merry's Tour and Travel by using the Technology Acceptance Model (TAM). This study uses a population of all management and employees of Merry's Tour and Travel. Determination of samples usingpurposive sampling techniques and the samples that met the criteria was 34 respondents. The data collection method uses a survey method with a questionnaire. Data were analyzed using Structural Equation Model (SEM), namely Partial Least Square (PLS). Based on the results of the analysis found that the variables of top management commitment, selft-efficacy, and perceived usefulness affect the acceptance of the QuickBooks information system at PT. Merry's Tour and Travel. This indicates that the process of transition from manual systems to QuickBooks information systems cannot be fully explained by the Technology Acceptance Model.
\end{abstract}

Keywords: $\quad$ Perceived Ease Of Use; Perceived Usefulness; Attitude Toward Using; Behavioral Intension To Use; Technology Acceptancemodel (TAM).

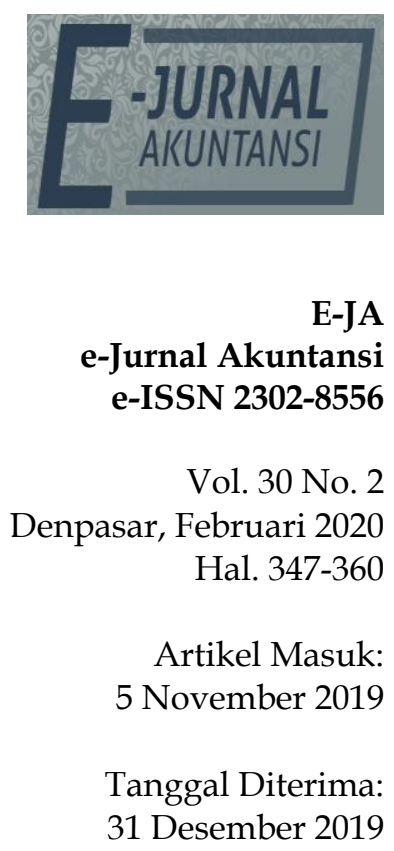

31 Desember 2019 


\section{PENDAHULUAN}

Perkembangan di berbagai bidang termasuk teknologiinformasi dan sains, ekonomi serta berbagai ketidakpastian yang dihadapiperusahaan adalah faktorfaktor yang mendorong perusahaan untuk melakukaninvestasi di bidang teknologi informasi. Begitu pula dalam bidang akuntansi, teknologi informasi sangat penting dalam menunjang proses pembuatan laporan keuanganAdapun salah satu dari program-program aplikasi akuntansi yang mumpuni yaitu program aplikasi QuickBooks. QuickBooks merupakan salah satu program aplikasi akuntansi untuk usaha kecil dan menengah yang dikembangkan dan dipasarkan oleh Intuit Inc., Amerika Serikat. Penelitian Compeau \& Higgins (1995) menyatakan bahwa tahapanyang kritis dalam usaha penerapan suatu sistem teknologi baru dalam perusahaan adalah kondisi dimana implementasi sistem tersebut diterima atau ditolak oleh karyawan. Model yang mampu memprediksi dan menjelaskan perilaku dari seorang individu termasuk pengguna teknologi adalah Technology Acceptance Model (TAM). TAM merupakan suatu model penerimaan yang dikembangkan oleh Davis (1989). Secara umum TAM memberikan uraian mengenai bagaimana sikap dan perilaku pengguna dalam penerimaan terhadap sistem baru berbasis teknologi. Adapun konstruk-konstruk yang digunakan dalam TAM, yaitu perceived usefulness, perceived ease of use, attitude toward using, behavioral intention to use, dan actual use.

Penerimaan suatu sistem teknologi informasi yang baru berdasarkan model TAM sangat dipengaruhi oleh attitude dan behavioral intention dari pihak pengguna. Attitude towards using didefinisikan oleh Davis (1989) sebagai perasaan-perasaan positif atau negatif dari seseorang jika harus melakukan sesuatu yang akan ditentukan. Apabila seseorang mempunyai sikap yang positif dalam menanggapi penggunaan sistem teknologi informasi yang baru, maka ia dikatakan memiliki ketertarikan untuk menggunakan teknologi tersebut. Kemudian,pengguna akan mempunyai keinginan (niat) untuk menggunakannya. Behavioral intention adalah keinginan seseorang untuk melakukan suatu perilaku tertentu. TAM menyatakan bahwa behavioral intension to use ditentukan oleh dua konstruk, yaitu: pertama, perceived usefulness yangdidefinisikan sebagai tingkat keyakinan seseorang tentang bagaimana menggunakan sistem akanmampu meningkatkan performa kerjanya (Taylor \& Todd 1995). Kedua, perceived ease of use yang didefinisikan sebagai tingkat keyakinan seseorang terhadap kemudahan dalam penggunaan sebuah sistem. Bersama-sama, kedua faktor ini memengaruhi attitude towards using dan selanjutnya behavioral intentionmereka untuk menggunakannya. Jika tahapan ini dirasakan secara positif maka pengguna dapat melanjutkan ke penggunaan teknologi yang sebenarnya (actual use) (Sullivan, Power, Ortiz, \& Italiano, 2017).

Lewis, Agarwal \& Sambamurthy (2003) menyatakan bahwa pengaruh variabel-variabel dalam model TAM terhadap pemanfaatan teknologi juga dijelaskan oleh institutional factor dan individual factor. Institutional factor dalam penelitian ini yaitu top management commitment. Manajemen melakukan pengambilan keputusan mengenai pemilihan hingga penerapan sistem. Keputusan penggunaan sistem informasi dalam suatu perusahaan yang dimulai dari penetapan strategi, pemilihan sistem, pengembangan sistem, operasionalisasi hingga tata kelola organisasi. Individual factor sebagai pengguna 
sistem teknologi informasi juga menjadi faktor yang signifikan. Individual factor dalam penelitian ini menggunakan self-efficacy yang berasal dari teori kognitif sosial yang mengemukakan bahwa dengan melihat orang lain melakukan sesuatu, maka seseorang akan mempunyai persepsi mengenai kemampuan dirinya dalam melakukan hal yang sama (Lewis et al. 2003).

Perusahaan membutuhkan teknologi informasi tidak hanya untuk mendukung kegiatan operasional perusahaan, namun juga untuk menciptakan competitive advantage bagi perusahaan. Begitu pula pada PT. Merry's Tourand Travel. Perusahaan PT. Merry's Tourand Travel yang didirikanpada tanggal 01 September 1992 oleh Bapak Misto Leo Faisal. Kantor cabang PT. Merry's Tourand Travel dapat ditemukan di Hotel Ramada Bintang Bali dan di Hotel Padma Resort. Pemilik perusahaan berencana untuk memperluas usaha dan berupaya meningkatkan kualitas pelayanan. Oleh karena itu, perusahaan harus memiliki sistem yang mampu memberikan informasi yang dapat dipercaya, relevan, tepat waktu, lengkap dan teruji keakuratannya untuk membantu semua bagian yang terlibat dengan transaksi yang menghasilkan laporan keuangan. Namun perusahaan sebelumnya hanya menggunakan pencatatan secara manual sehingga, pihak manajemen perusahaan memutuskan untuk menguji coba penggunaan program aplikasi QuickBooks. Dengan diuji cobanya sistem ini diharapkan dapat meningkatkan keahlian karyawan, memotong biaya dan memperbaiki kualitas laporan keuangan.

Dukungan manajemen puncak diperlukan untuk memotivasi individu karyawan untuk menggunakan sistem karena adanya dukungan dan perhatian sumber daya finansial dan non finansial (Sarastini \& Suardikha, 2017). Hasil penelitian Utama (2012) menyatakan bahwa top management commitment berpengaruh positif pada perceived usefulness. Hasil temuan ini konsisten dengan temuan Lewis et al. (2003) bahwa persepsi top management support memiliki pengaruh positif dalam keyakinan individual mengenai perceived usefulness dalam penggunaan teknologi. Berdasarkan uraian di atas, maka dapat dihipotesiskan:

$\mathrm{H}_{1 \mathrm{a}}$ : Top management commitment berpengaruh positif pada percieved usefulness dalam penggunaan sistem QuickBooks.

Lewis et al. (2003) menemukan bahwa persepsi top management support memiliki pengaruh positif dalam keyakinan individual mengenai percieved ease of use dalam penggunaan teknologi dan penelitian yang dilakukan oleh Aristo (2017) menunjukkan bahwa dukungan manajemen puncak memiliki pengaruh terhadap tingkat kesuksesan dalam implementasi sistem teknologi informasi baru. Berdasarkan uraian tersebut, maka hipotesis yang diajukan dalam penelitian ini adalah sebagai berikut:

$\mathrm{H}_{1 \mathrm{~b}}$ : Top management commitment berpengaruh positif pada percieved ease of use sistem QuickBooks.

Self-efficacy pengguna akan mempengaruhi perceived ease of use dan perceived usefulness dalam upaya implementasi teknologi informasi. Semakin seseorang memiliki self-efficacy yang tinggi maka semakin tinggi pula keyakinan terhadap kemampuan yang dimilikinya untuk dapat menggunakan teknologi informasi baru. Bandura (1994) menyatakan bahwa penelitian-penelitian mengenai self-efficacy menghasilkan sebuah perspektif bahwa perceived ease of use 
dan perceived usefulness merupakan determinan penting bagi perilaku user. Hasil temuan yang sama yaitu, Penelitian Suardikha et al. (2012), Lewis et al. (2003), dan Kartika (2009). Berdasarkan uraian tersebut, maka hipotesis yang diajukan dalam penelitian ini adalah sebagai berikut:

$\mathrm{H}_{2 \mathrm{a}}$ : Self-Efficacy berpengaruh positif pada percieved usefulness dalam penggunaan sistem QuickBooks.

Penelitian Utama, Wibowo \& Nurhadi (2014) dan Suardikha et al. (2012) mengungkapkan bahwa self-efficacy berpengaruh positif pada percieved ease of use. Hasil temuan didukung oleh hasil penelitian dari Lewis et al. (2003) dan Suardikha et al. (2012) bahwa self-efficacy memiliki pengaruh positif dalam keyakinan individual mengenai percieved ease of use dalam penggunaan teknologi. Penelitian Kartika (2009) juga menemukan bahwa self-efficacy mempunyai pengaruh yang positif padapercieved ease of use dalam penggunaan sistem informasi. Berdasarkan uraian tersebut, maka hipotesis yang diajukan dalam penelitian ini adalah sebagai berikut:

$\mathrm{H}_{2 \mathrm{~b}}$ : Self-Efficacy berpengaruh positif pada percieved ease of use dalam penggunaan sistem QuickBooks.

Davis (1989) mendefinisikan perceived ease of usesebagai tingkat keyakinan dari seseorang dalam upaya menggunakan suatu sistem dianggap tidakmemerlukan usaha yang keras. Apabila jasa yang diberikan teknologi dipersepsikan mudah digunakan oleh para pengguna maka akan mendorong para pengguna untuk menerima dan menggunakan teknologi tersebut. Penelitian yang dilakukan oleh Primawati (2015), Sari (2016), Hanggono, Handayani \& Susilo (2015), Paramita \& Mudjahidin (2014), Utama et al. (2014) serta Muntianah, Astuti \& Azizah (2012) menunjukkan bahwa adanya pengaruh yang positif antara percieved ease of use terhadap perceived usefulness. Berdasarkan uraian tersebut, maka hipotesis yang diajukan dalam penelitian ini adalah sebagai berikut:

$\mathrm{H}_{3 \mathrm{a}}$ : Perceived ease of use berpengaruh positif pada perceived usefulness dalam penggunaan sistem QuickBooks.

Myristika (2014) dalam penelitian mengenai analisis penerimaan mahasiswa terhadap sistem informasi akademik berbasis web di Universitas Brawijaya dengan menggunakan Technology Acceptance Model (TAM) membuktikan bahwa kemudahan penggunaan persepsian (perceived ease of use) berpengaruh positif pada sikap terhadap perilaku (attitude toward using). Nugraha \& Laksito (2014), Sidharta \& Rahmahwati (2014), Latifah \& Afifah (2013) dan Kartika (2013) memperoleh hasil yang sama. Berdasarkan uraian tersebut, maka hipotesis yang diajukan dalam penelitian ini adalah sebagai berikut:

$\mathrm{H}_{3 \mathrm{~b}}$ : Perceived ease of use berpengaruh positif pada attitudetoward using dalam penggunaan sistem QuickBooks.

Persepsi kegunaan (percieved usefulness) merupakan salah satu determinan yang mempengaruhi sikap terhadap perilaku (attitudetoward using). Sikap pengguna yang mendukung penggunaan teknologi sistem informasi akan secara otomatis mendorong pemanfaatan serta penggunaan yang lebih intens dari teknologi sistem informasi. Hasil dari penelitian Kartika (2013), Bangkara \& Mimba (2016), Paramita \& Mudjahidin (2014) serta Latifah \& Afifah (2013) 
memnemukan bahwa perceived usefulness berpengaruh positif pada attitude toward using. Berdasarkan uraian tersebut, maka hipotesis yang diajukan dalam penelitian ini adalah sebagai berikut:

$\mathrm{H}_{4 a}$ : Percieved usefulness berpengaruh positif pada attitudetoward usingdalam penggunaan sistem QuickBooks.

Paramita \& Mudjahidin (2014) dan Muntianah et al. (2012) dalam penelitiannya membuktikan bahwa terdapat pengaruh positif antara persepsi kegunaan (perceived usefullness) dengan niat perilaku (behavioral intention). Penelitian Aditya \& Wardhana (2016) menemukan bahwa persepsi kegunaan (perceived usefullness) dari pengguna sistem informasi mempengaruhi minatnya dalam menggunakan sistem informasi untuk membantu kinerjanya. Berdasarkan uraian tersebut, maka hipotesis yang diajukan dalam penelitian ini adalah sebagai berikut:

$\mathrm{H}_{4 \mathrm{~b}}$ : Percieved usefulness berpengaruh positif pada behavioral intention to usedalam penggunaan sistem QuickBooks.

Sikap (attitude) seseorang dapat dinilai dari kemauan seseorang untuk bersedia menggunakan sebuah sistem. Semakin tinggi keinginan seseorang untuk menggunakan sebuah sistem informasi, maka akan semakin sering intensi untuk menggunakannya. Dengan demikian dapat dikatakan terdapat pengaruh antara sikap terhadap perilaku (attitude toward using) pada niat perilaku (behavioral intention to use)(Nugraha \& Laksito, 2014). Hasil penelitian Hanggono et al.(2015), Nugraha \& Laksito (2014)dan Sidharta \& Rahmahwati (2014). Berdasarkan uraian tersebut, maka hipotesis yang diajukan dalam penelitian ini adalah sebagai berikut:

$\mathrm{H}_{5}$ : Attitudetowards using berpengaruh positif pada behavioral intention to use dalam penggunaan sistem QuickBooks.

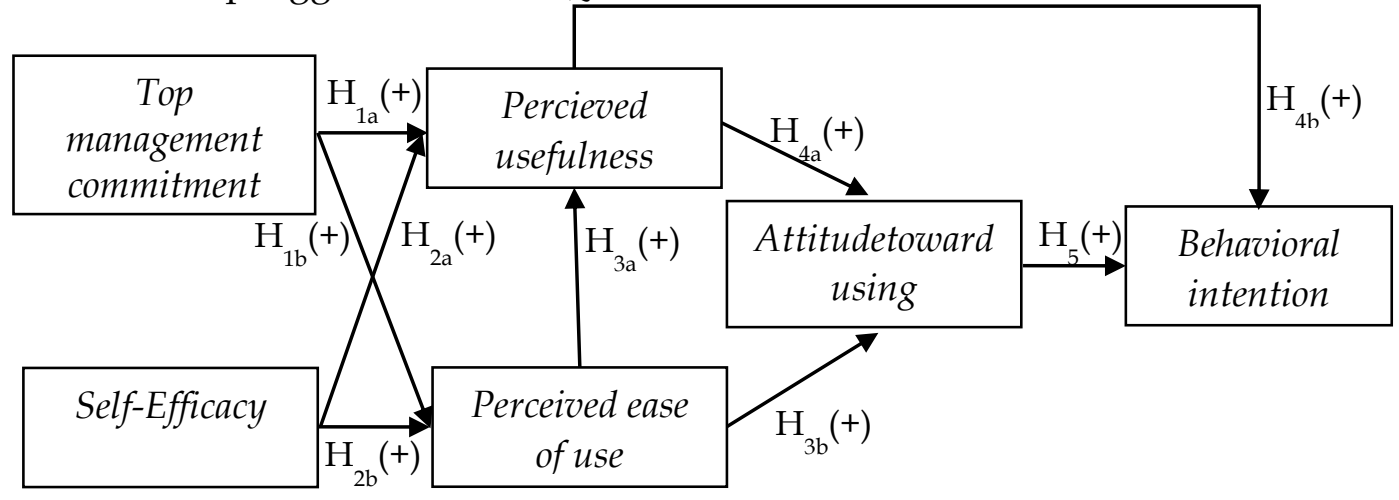

Gambar 1. Model Penelitian

Sumber: Data Penelitian, 2019

\section{METODE PENELITIAN}

Penelitian ini dilakukan pada perusahaan PT. Merry's Tour and Travel dengan obyek penerimaan sistem aplikasi QuickBooks oleh karyawan. Populasi pada penelitian ini adalah manajemen dan karyawan PT. Merry's Tour and Traveldengan kriteria sampelseluruh karyawan yang terlibat dalam sistemsehingga diperoleh 34 orang responden yang memenuhi kriteria. Metode pengumpulan data yang digunakan dalam penelitian ini adalah melalui 
kuesioner dengan pengukuran masing-masing indikatormenggunakan skala likert 1 sampai dengan 5, yakni: Sangat Setuju (SS) diberi skor 5, Setuju (S) diberi skor 4, Tidak Pasti (TP) diberi skor 3, Tidak Setuju (TS) diberi skor 2, dan Sangat Tidak Setuju (STS) diberi skor 1. Instrumen yang digunakan adalah instrumen yang pernah digunakan dalam penelitian Suardikha et al.( 2012) dan Kartika (2009) sehingga memungkinkan untuk meningkatkan reliabilitas dan validitas pengukuran. Ghozali (2011) dalam Nugraha \& Laksito (2014) mengemukakan bahwa pengujian reliabilitas dapat dilakukan dengan melihat nilai dari composite reliability yang mengukur internal consistency dan nilainya harus diatas 0,60 untuk dikatakan reliabel. Uji validitas indikator penelitian dapat dikatakan valid apabila nilai uji faktor/R kritis $>0,3$.

Analisis data dilakukan dengan menggunakan analisis statistik deskriptif dan Partial Least Square PLS. Analisis statistik deskriptif digunakan untuk mendeskripsikan atau memberikan gambaran dari nilai minimum, nilai maksimum, rata-rata (mean) dan standar deviasi dari masing-masing variabel penelitian yaitu, top management commitment $\left(\mathrm{X}_{1}\right)$, selft-efficacy $\left(\mathrm{X}_{2}\right)$, perceived ease of use $\left(\mathrm{Y}_{1}\right)$, perceived usefulness $\left(\mathrm{Y}_{2}\right)$, attitude toward using $\left(\mathrm{Y}_{3}\right)$ dan behavioral intention to use $\left(\mathrm{Y}_{4}\right)$. Analisis Partial Least Square PLS dilakukan dalam tiga tahap pengujian, yang pertama adalah analisis outer model yang didefinisikan bagaimana setiap indikator berhubungan dengan variabel latennya. Pada tahap ini terdapat tiga tahap pengujian yang akan dilakukan, yaitu: Convergent validity, Discriminat validity, dan Composite reliability.Kedua, analisis inner model, dilakukan untuk memastikan bahwa model struktural yang dibangun kuat dan akurat. Beberapa tahap yang akan dilakukan pada inner model, yaitu: Estimate for Path Coefficients, Evaluasi nilai $\mathrm{R}^{2}$, dan Struktural $\mathrm{Q}^{2}$ (predictive relevance).Ketiga, pengujian hipotesis dimana dapat dilakukan dengan melihat nilai t-statistik dan nilai probabilitas. Pengujian hipotesis dengan menggunakan nilai statistik sehingga untuk alpha $5 \%$ maka nilai t-statistik yang dapat digunakan adalah 1,96 .

\section{HASIL DAN PEMBAHASAN}

Hasil pengujian reliabilitas dan validitas padakuesioner menunjukkan bahwa kuesioner valid dan reliabel. Hasil uji reliabilitas menunjukkan nilai croanbach alpha dari konstruk lebih dari 0,6 sehingga sembilan konstruk dalam penelitian ini dapat dikatakan baik atau reliabel. Berdasarkan hasil uji validitas, nilai setiap indikator lebih besar dari 0,3 sehingga dapat dikatakan valid.

Uji statistik deskriptif mengelompokkan jumlah responden pria sebanyak 8 orang dan wanita 24 orang dengan rentang usia karyawan sebagai berikut:2029 tahun sebanyak 18 responden (53\%), 30-39 tahun sebanyak 11 responden (32\%), 40-49 tahun sebanyak 5 responden (15\%), Hal ini menunjukkan bahwa karyawan masih produktif dalam bekerja. Tingkat pendidikan karyawan antara lain, SMA sebanyak 6responden (17\%), Diploma sebanyak 20 responden (59\%), S1 sebanyak 8responden (24\%), dapat diartikan bahwa sebagian besar karyawan memiliki pendidikan cukup untuk belajar mengenai sistem baru yang diterapkan. Manajemen seluruhnya berjumlah 3 responden $(9 \%)$, back office sebanyak 26 responden(76\%) dan Operational sebanyak 5 responden(15\%) yang dipilih sebagai sampel dalam penelitian. Berdasarkan hasil uji analisis statistik 
deskriptifdiperoleh nilai mean (rata-rata) pada setiap variabel yaitu top management commitment sebesar 4,39, selft-efficacy sebesar 4,22, perceived ease of use sebesar 4,37, perceived usefulness sebesar 4,37, attitude toward using sebesar 4,33 dan behavioral intention to use sebesar 4,32 sehingga nilai setiap konstruk berada pada rentang skala 4-5 yang berarti dari skala 1-5, range jawaban responden terletak pada setuju dan sangat setuju.

Pengujian convergent validity dalam evaluasi outer model pada PLS SEM dapat dinilai dari korelasi antara skor item. Menurut Chin (1998) indikator pada tahap pengembangan skala pengukuran penelitian dikatakan tinggi apabila memiliki nilai cross loading berkisar 0,50 sampai 0,60. Pada penelitan ini nilai cross loading yang digunakan adalah 0,60 . Hasil uji convergent validity menunjukkan nilai masing-masing indikator dalam setiap konstruk memiliki nilai cross loading lebih besar dari 0,60 sehingga dapat dikatakan setiap konstruk dalam penelitian ini memiliki convergent validity yang tinggi.

Pengujian kedua dalam evaluasi outer model yaitu discriminat validityyang digunakan untuk mengukur seberapa jauh suatu konstruk berbeda dari konstruk lainnya. Nilai discriminant validity yang tinggi diartikan bahwa konstruk tersebut unik dan mampu menangkap fenomena yang diukur. Hal yang dilakukan untuk menguji discriminant validity yaitu nilai akar kuadrat dari square root of Average Variance Extracted (AVE) harus lebih besar dari nilai korelasi antar variabel laten. Hasil uji discriminat validity dapat dilihat dari Tabel 1. dan Tabel 2.

Tabel 1. Korelasi Variabel Laten

\begin{tabular}{lllllll}
\hline & ATU & BI & PEOU & PU & SE & TMC \\
\hline Top Management & 0,389 & 0,654 & 0,767 & 0,648 & 0,696 & 1,000 \\
Commitment (TMC) & & & & & & \\
Self-Efficacy (SE) & 0,573 & 0,750 & 0,686 & 0,721 & 1,000 & 0,696 \\
Perceived Easy of Use (PEOU) & 0,410 & 0,664 & 1,000 & 0,691 & 0,686 & 0,767 \\
Perceived Usefulness (PU) & 0,744 & 0,765 & 0,691 & 1,000 & 0,721 & 0,648 \\
Attitude Toward Using (ATU) & 1,000 & 0,675 & 0,410 & 0,744 & 0,573 & 0,389 \\
Behavioral Intention (BI) & 0,675 & 1,000 & 0,664 & 0,765 & 0,750 & 0,654 \\
\hline
\end{tabular}

Sumber: Data Penelitian, 2019

Pada Tabel 1. menunjukkan bahwa nilai akar AVE terendah yaitu 0,769. Nilai ini kemudian dibandingkan dengan nilai korelasi antar variabel laten yang dapat dilihat pada Tabel 2.

Tabel 2. Akar AVE

\begin{tabular}{lll}
\hline & AVE & Akar AVE \\
\hline Top Management Commitment & 0,872 & 0,934 \\
Self-Efficacy & 0,882 & 0,939 \\
Perceived Easy of Use & 0,684 & 0,827 \\
Perceived Usefulness & 0,591 & 0,769 \\
Attitude Toward Using & 0,638 & 0,799 \\
Behavioral Intention & 0,793 & 0,891 \\
\hline
\end{tabular}

Sumber: Data Penelitian, 2019

Pada Tabel 2. menunjukkan bahwa nilai korelasi antar konstruk tertinggi adalah 0,767. Oleh karena nilai akar AVE terendah yaitu sebesar 0,769 lebih tinggi dari nilai korelasi antar konstruk tertinggi yaitu sebesar 0,767, hal ini berarti seluruh konstruk memiliki discriminat validity tinggi dan mampu menangkap fenomena yang diukur. 
Pengujian ketiga yaitu composite reliablity. Suatu konstruk dapat dikatakan reliable apabila memiliki nilai composite reliability lebih besar dari 0,60 (Ghozali 2014). Hasil uji composite reliablity dapat dilihat pada Tabel 3.

Tabel 3. Construct Reliability dan Validity

\begin{tabular}{lllll}
\hline & Cronbach's Alpha & rho_A & $\begin{array}{l}\text { Composite } \\
\text { Reliability }\end{array}$ & $\begin{array}{l}\text { Average Variance } \\
\text { Extracted (AVE) }\end{array}$ \\
\hline TMC & 0,927 & 0,927 & 0,954 & 0,872 \\
SE & 0,933 & 0,948 & 0,957 & 0,882 \\
PEOU & 0,883 & 0,891 & 0,915 & 0,684 \\
PU & 0,826 & 0,830 & 0,878 & 0,591 \\
ATU & 0,712 & 0,728 & 0,840 & 0,638 \\
BI & 0,869 & 0,870 & 0,920 & 0,793 \\
\hline
\end{tabular}

Sumber: Data Penelitian, 2019

Keterangan:

$\mathrm{TMC}=$ Top management commitment

$\mathrm{SE} \quad=$ Self-efficacy

PEOU $=$ Perceived ease of use

PU = Perceived usefulness

ATU = Attitude toward using

BI = Behavioral intention

Hasil composite reliablity yang tinggi yaitu attitude toward using $(0,840)$, behavioral intention $(0,920)$, perceived ease of use $(0,915)$, perceived usefulness $(0,878)$, self-efficacy $(0,957)$, dan top management commitment $(0,954)$. Masing-masing konstruk memiliki reliabilitas tinggi karena nilai compositereliability seluruh konstruk di atas 0,60 sehingga dapat diartikan bahwa setiap konstruk dalam penelitian ini memiliki konsistensi yang tinggi.

Tahapan pengujian PLS yang kedua yaitu evaluasi Inner modelyang digunakan untuk mengevaluasi hubungan antar konstruk laten sesuai dengan hipotesis dalam penelitian. Tahap pengujian pertama dalam evaluasi inner model, yaitu estimate for path coefficients. Nilai estimasi untuk hubungan jalur dalam model struktural harus signifikan. Signifikan diperoleh melalui prosedur bootstrapping yang juga menghasilkan nilai $\mathrm{T}$ ( $\mathrm{T}$-value), dimana $\mathrm{t}$ hitung $>\mathrm{t}$ Tabel 1,96 ditunjukkan pada Tabel 4 .

Tabel 4. Path Coefficients

\begin{tabular}{llllll}
\hline & $\begin{array}{l}\text { Original } \\
\text { Sample } \\
(\mathrm{O})\end{array}$ & $\begin{array}{l}\text { Sample } \\
\text { Mean }(\mathrm{M})\end{array}$ & $\begin{array}{l}\text { Standard } \\
\text { Deviation } \\
(\text { STDEV })\end{array}$ & $\begin{array}{l}\text { T Statistics } \\
(|\mathrm{O} / \mathrm{STDEV}|)\end{array}$ & P Values \\
\hline TMC -> PU & 0,107 & 0,115 & 0,180 & 0,596 & 0,276 \\
TMC -> PEOU & 0,563 & 0,538 & 0,215 & 2,620 & 0,005 \\
SE -> PU & 0,433 & 0,406 & 0,182 & 2,377 & 0,010 \\
SE -> PEOU & 0,294 & 0,315 & 0,218 & 1,352 & 0,090 \\
PEOU -> PU & 0,312 & 0,331 & 0,160 & 1,944 & 0,027 \\
PEOU -> ATU & $-0,200$ & $-0,223$ & 0,134 & 1,485 & 0,070 \\
PU -> ATU & 0,882 & 0,901 & 0,098 & 9,016 & 0,000 \\
PU -> BI & 0,599 & 0,616 & 0,139 & 4,317 & 0,000 \\
ATU -> BI & 0,229 & 0,227 & 0,163 & 1,406 & 0,081 \\
\hline
\end{tabular}

Sumber: Data Penelitian, 2019 
Tabel 4. menunjukkan bahwa konstruk attitude toward using tidak berpengaruh pada behavioral intention dengan nilai $1,406<\mathrm{t}$ Tabel 1,96. perceived ease of use tidak berpengaruh pada attitude toward using dengan nilai 1,485 $<\mathrm{t}$ Tabel 1,96. Perceived ease of use tidak berpengaruh pada perceived usefulness dengan nilai 1,944 < t Tabel 1,96. Self-Efficacy tidak berpengaruh pada perceived ease of use dengan nilai 1,352 < t Tabel 1,96. Top management commitmenttidak berpengaruh pada perceived usefulness dengan nilai 0,596 < $t$ Tabel 1,96, sedangkan konstruk yang lain menunjukkan pengaruh yang signifikan.

Tahap pengujian kedua yaitu evaluasi nilai $\mathrm{R}^{2}$ yang berarti besarnya variability variabel endogen yang mampu dijelaskan oleh variabel eksogen. Chin \& Lin (2015) menjelaskan kriteria R ${ }^{2}$ terdiri dari tiga klasifikasi nilai $\mathrm{R}^{2}$ yaitu: 0,67, 0,33dan 0,19 yang berarti substansial, moderate dan lemah. Hasil uji $\mathrm{R}^{2}$ nilai $\mathrm{R}^{2}$ attitude toward usingsebesar 0,575 yang artinya variabel perceived ease of use, perceived usefulness dapat menjelaskan $57,5 \%$ perubahan dari variabel attitude toward using dan sisanya sebesar $42,5 \%$ dipengaruhi oleh faktor lain, ini berarti variabel attitude toward using adalah moderat. $R^{2}$ behavioral intention sebesar 0,615 yang artinya variabel perceived ease of use, perceived usefulness, attitude toward using dapat menjelaskan 61,5 \% perubahan dari variabel behavioral intention dan sisanya sebesar 38,5\% dipengaruhi oleh faktor lain, yang artinyabehavioral intention adalah moderat. $\mathrm{R}^{2}$ perceived ease of usesebesar 0,634 yang artinya variabel top management commitment, self-efficacy dapat menjelaskan 63,4\% perubahan dari variabel perceived ease of use dan sisanya sebesar 36,6\% dipengaruhi oleh faktor lain, yang artinya variabel perceived ease of use adalah moderat. $\mathrm{R}^{2}$ perceived usefulness sebesar 0,597 yang artinya variable perceived ease of use, top management commitment, dan self-efficacy dapat menjelaskan 59,7\% perubahan dari variabel perceived usefulness dan sisanya sebesar 40,3\% dipengaruhi oleh faktor lain, artinya variabel perceived usefulness adalah moderat. Pengujian ketiga dalam evaluasi inner modelyaitu $Q^{2}$ predictive relevance yang digunakan untuk mengukur nilai observasi yang dihasilkan oleh model dan estimasi parameternya. Hasil $Q^{2}$ dikatakan baik jika nilainya $Q^{2>} 0$. Hasil pengujian menunjukkan nilai $Q^{2}$ adalah $0,976>0$ yang menunjukkan bahwa model dan parameternya memiliki predictive relevance yang baik karena konstruk TAM memiliki nilai lebih besar dari 0 dan mendekati 1, sehingga nilai observasi terhadap konstruk adalah baik. Tahap pengujian terakhir yaitu pengujian hipotesis pada sembilan hipotesis yang diajukan ditunjukkan pada Tabel 6 .

Tabel 6. Hasil Uji Hipotesis

\begin{tabular}{llllll}
\hline Hipotesis & Konstruk & Estimates & T Statistik & Pengaruh & Keterangan \\
\hline 1 & TMC -> PU & 0,107 & 0,596 & Langsung & $\mathrm{H}_{1 \mathrm{a}}$ Ditolak \\
2 & TMC -> PEOU & 0,563 & 2,620 & Langsung & $\mathrm{H}_{1 \mathrm{~b}}$ Diterima \\
3 & SE -> PU & 0,433 & 2,377 & Langsung & $\mathrm{H}_{2 \mathrm{a}}$ Diterima \\
4 & SE -> PEOU & 0,294 & 1,352 & Langsung & $\mathrm{H}_{2 \mathrm{~b}}$ Ditolak \\
5 & PEOU -> PU & 0,312 & 1,944 & Langsung & $\mathrm{H}_{4 \mathrm{a}}$ Ditolak \\
6 & PEOU -> ATU & $-0,200$ & 1,485 & Langsung & $\mathrm{H}_{4 \mathrm{~b}}$ Ditolak \\
7 & PU -> BI & 0,599 & 4,317 & Langsung & $\mathrm{H}_{3 \mathrm{a}}$ Diterima \\
8 & PU -> ATU & 0,882 & 9,016 & Langsung & $\mathrm{H}_{3 \mathrm{~b}}$ Diterima \\
9 & ATU -> BI & 0,229 & 1,406 & Langsung & $\mathrm{H}_{5}$ Ditolak \\
\hline
\end{tabular}

Sumber: Data Penelitian, 2019 
Hasil uji hipotesis $\mathrm{H}_{1 a}$ ditemukan bahwa top management commitment tidak berpengaruh pada perceived usefulness dengan nilai $\mathrm{t}$ hitung sebesar 0,596 < $\mathrm{t}$ Tabel 1,96. Hasil ini tidak sesuai dengan pendapat Davis (1989) menyatakan bahwa faktor eksternal dalam model berpengaruh pada perceived ease of use dan perceived usefulness. Lewis et al. (2003) juga menyatakan bahwa Technology Acceptance Model (TAM) dipengaruhi oleh institutional factor pada penerimaan sistem informasi teknologi. Tidak signifikannya pengaruh top management commitment pada perceived usefulness dikarenakan perusahaan tidak memberikan cukup peluang kepada para karyawannya untuk ikut serta dalam pengembangan sistem.Hasil uji hipotesis $\mathrm{H}_{1 \mathrm{~b}}$ membuktikan bahwa top management commitment berpengaruh pada perceived ease of use dalam penggunaan sistem informasi QuickBooks dengan nilai $t$ hitung sebesar 2,620 > t Tabel 1,96. Hasil ini sesuai dengan pendapat Davis (1989), Utama (2012), Aristo (2017), dan Lewis et al. (2003). Sehingga dapat disimpulkan, apabila manajemen puncak memberikan dukungan penuh pada karyawan, baik dalam kepemimpinan maupun penyediakan sumber daya berpengaruh pada kemudahan penggunaan sistem baru tersebut. Perusahaan PT. Merry's Tour and Travel menyediakan prosedur yang memadai dan trainer yang berpengalaman untuk memberi bimbingan dan saran dalam menggunakan aplikasi QuickBooks sehingga sistem lebih jelas dan mudah untuk dipahami.

Hasil pengujian hipotesis $\mathrm{H}_{2 a}$ menunjukkan bahwa variabel self-efficacy berpengaruh pada perceived usefulness dalam penggunaan sistem informasi QuickBooks dengan nilai $\mathrm{t}$ hitung sebesar 2,377 > t Tabel 1,96. Karyawan merasa yakin bahwa mereka bisa mengoperasikan aplikasi QuickBooks dalam operasional perusahaan serta penggunaannya dapat meningkatkan kemampuan kerja mereka. Hasil penelitian ini sesuai dengan penelitian oleh Bandura (1994), Suardikha et al. (2012), Lewis et al. (2003) dan Kartika (2009)yang menemukan bahwa self-efficacy memiliki pengaruh padaperceived usefulness. Hasil uji hipotesis $\mathrm{H}_{2 \mathrm{~b}}$ membuktikan bahwa variabel self-efficacytidakberpengaruh pada perceived ease of use dalam penerimaan penggunaan sistem QuickBooksdi PT. Merry's Tour and Travel dengan nilai $\mathrm{t}$ hitung sebesar 1,352< $\mathrm{t}$ Tabel 1,96. Hasil penelitian ini tidak sesuai dengan pendapat Davis (1989) yang menyatakan bahwa faktor eksternal dalam model berpengaruh pada perceived ease of use dan Lewis et al. (2003) menyatakan bahwa Technology Acceptance Model (TAM) dipengaruhi oleh individual factor pada penerimaan sistem informasi teknologi. Hal ini membuktikan bahwa mudah atau tidaknya sistem tidak dapat dijelaskan oleh tingkat kemampuan karyawan dalam lingkungan mandatory use, kemudahan penggunaan sistem informasi QuickBooks tidak signifikan karena pengguna tidak memiliki pilihan dalam menentukan sistem informasi yang mereka sukai melainkan ditetapkan oleh manajemen. Oleh karena itu, karyawan PT. Merry's Tour and Travel merasa tidak yakin bahwa mereka bisa mengoperasikan sistem dan perusahaan kurang memberi kebebasan pada karyawan untuk mampu beradaptasi dengan sistem yang baru. Hasil penelitian ini sesuai dengan hasil penelitian yang dilakukan oleh Santoso \& Setiawan (2017) yang menemukan tidak adanya pengaruh self-efficacy pada perceived easy of use.

Hasil uji hipotesis $\mathrm{H}_{3 a}$ menunjukkan bahwa variabel perceived ease of usetidak berpengaruh pada perceived usefulness terhadap penggunaan sistem 
QuickBooks dengan nilai $\mathrm{t}$ hitung sebesar 1,944< $\mathrm{t}$ Tabel 1,96.Penemuan ini tidak sesuai dengan pendapat Davis (1989)dan hasil penelitian dari Sari (2016), Hanggono et al. (2015), Paramita \& Mudjahidin (2014), Utama et al. (2014) dan Muntianah et al. (2012) yang menyatakan bahwa kemudahan penggunaan dapat menjadi anteseden terhadap kegunaan dalam penerimaan teknologi informasi. Penolakan hipotesis ini disebabkan oleh karyawan PT. Merry's Tour and Travelmerasa bahwa penggunaan aplikasi QuickBooks cukup sulit untuk digunakan. Oleh karena itu, karyawan merasa penggunaan sistem tidak meningkatkan efektifitas mereka dalam bekerja. Hasil uji hipotesis $\mathrm{H}_{3 b}$ menunjukkan bahwa variabel perceived ease of usetidak berpengaruh pada variabelattitude toward using dengan nilai t hitung sebesar 1,485 < t Tabel 1,96. Hasil ini bertentangan dengan hasil penelitian dari Davis (1989) yang menyatakan bahwa perceived ease of usemempengaruhiperceived usefulness dan attitude toward using. Namun hasil penelitian ini sesuai denganhasil penelitian yang dilakukan oleh Kartika (2009), Muntianah et al. (2012) dan Sidharta \& Rahmahwati (2014). Penolakan ini dapat diartikan sebagai perasaan tidak percaya karyawan akan sistem. Oleh karena karyawan merasa bahwa sistem yang baru cukup sulit untuk digunakan, sehingga sulitnya sistem untuk dipahami menyebabkan penggunaan sitem menjadi tidak begitu menyenangkan bagi karyawan.

Hasil pengujian hipotesis $\mathrm{H}_{4 \mathrm{a}}$ dan $\mathrm{H}_{4 \mathrm{~b}}$ menunjukkan bahwa variabel perceived usefulness berpengaruh pada variabelattitude toward usingdan behavioral intention dengan nilai $\mathrm{t}$ hitung masing-masing sebesar 9,016 > t Tabel 1,96 dan 4,317 > t Tabel 1,96 yang berarti kegunaan sistem informasi QuickBooks berpengaruh pada sikap positif dan niat karyawan menggunakan sistem informasi dalam membantu operasional pekerjaannya. Hasil penelitian ini sesuai dengan hasil penelitian yang dilakukan Bangkara \& Mimba (2016), Paramita \& Mudjahidin (2014), Latifah \& Afifah (2013) dan Kartika (2013). Dengan digunakannya sistem aplikasi QuickBooks kemampuan kerja para karyawan dapat ditingkatkan. Interaksi dengan sistem dipersepsi tidak membosankan serta dapat memudahkan karyawan dalam melakukan pekerjaan mereka. Sehingga karyawan mencoba untuk lebih sering menggunakan sistem untuk meningkatkan keterampulan dalam menggunakannya.

Hasil uji hipotesis $\mathrm{H}_{5}$ menunjukkan bahwa variabel attitude toward usingtidak berpengaruh pada variabelbehavioral intention dengan nilai $\mathrm{t}$ hitung sebesar 1,406 < t Tabel 1,96. Hasil ini berbeda dengan hasil penelitian Latifah \& Afifah (2013), Kartika (2013), dan juga Sulistyarini (2012) yang menemukan bahwa bahwa attitudetowards using mempunyai pengaruh positif pada behavioral intention to use. Namun, hasil ini sesuai dengan hasil penelitian Muntianah et al. (2012). Hal ini berartiinteraksi karyawan dengan sistem tidak begitu dipahami oleh karena itu karyawan tidak selalu menggunakan sistem untuk mengerjakan tugas mereka. Dari hasil kuesioner yang diperoleh, frekuensi penggunaan sistem QuickBooks oleh karyawan cenderung rendah yaitu 1-10 kali dalam sebulan atau $71 \%$ dari penggunaan sistem secara keseluruhan oleh karyawan. 


\section{SIMPULAN}

Berdasarkan hasil yang diperoleh, berikut pengaruh yang terbukti signifikan antara lain: a) top management commitmentpadaperceived ease of use, b) selfefficacypadaperceived usefulness, c) perceived usefulnesspadaattitude toward using, dan d) perceived usefulness pada behavioral intention to use. Hal ini membuktikan bahwa proses transisi perubahan dari sistem manual ke sistem informasi QuickBooks tidak sepenuhnya dapat dijelaskan oleh Technology Acceptance Model. Penerapan aplikasi sebuah sistem baru dapat dilakukan tanpa mempertimbangkan sikap, kepercayaan diri karyawan, kesukarelaan karyawan untuk memanfaatkan sistem informasi, maupun persepsi mengenai sulit atau mudahnya penggunaan sistem informasi tidak berpengaruh pada keiinginan karyawan untuk menggunakan sistem yang ditetapkan perusahaan. Oleh karena itu, untuk menerapkan suatu sistem baru perusahaan lebih perlu mengedepankan biaya dan manfaat dari sistem yang hendak digunakan. Penelitian selanjutnya dapat menggunakan variabel eksternal lain yang didasarkan pada pendapat Lewis et al. (2003) yaitu faktor institusional, faktor sosial dan faktor individualsecara bersama-sama pada beberapa organisasi dengan skala industri yang berbeda sehingga sampel yang digunakan lebih besar dengan dan alat analisis yang berbeda seperti AMOS, LISREL.

\section{REFERENSI}

Aditya, R., \& Wardhana, A. (2016). Pengaruh Perceived Usefulness dan Perceived Ease Of Use terhadap Behavioral Intention dengan Pendekatan Technology Acceptance Model (TAM) pada Pengguna Instant Messaging LINE di Indonesia. Jurnal Siasat Bisnis, 20(1), 24-32. https:// doi.org/10.20885/jsb.vol20.iss1.art3

Aristo, J. (2017). Proyek dan Keterlibatan Pengguna terhadap Kesuksesan Implementasi Enterprise Resouce Planning. Jurnal Riset Manajemen Dan Bisnis (JRMB) Fakultas Ekonomi UNIAT 1, 2(2), 147-154.

Bandura, A. (1994). Bandura Self-efficacy defined. Encyclopedia of Human Behavior. Retrieved from http://www.uky.edu/ eushe2/Bandura/BanEncy.html

Bangkara, R. P., \& Mimba, N. P. S. H. (2016). Pengaruh Perceived Usefulness dan Perceived Ease of Use pada Minat Penggunaan Internet Banking dengan Attitude Toward Using Sebagai Variabel Intervening. Jurnal Akuntansi Universitas Udayana, 16(3), 2302-8556. https://doi.org/10.1088/0031-9155/47/24/301

Chin, J., \& Lin, S. C. (2015). Investigating Users' Perspectives in Building Energy Management System with an Extension of Technology Acceptance Model: A Case Study in Indonesian Manufacturing Companies. Procedia Computer Science, 31-39. https://doi.org/10.1016/j.procs.2015.12.102

Chin, W. (1998). The partial least squares approach to structural equation modeling. Modern Methods for Business Research, 295(2), 295-336. https://doi.org/10.1016/j.aap.2008.12.010 
Compeau, D., \& Higgins, C. (1995). Application of social cognitive theory to training for computer skills. Information Systems Research, 6(2), 118143. https://doi.org/10.1287/isre.6.2.118

Davis, F. (1989). Perceived Usefulness, Perceived Ease Of Use, And User Acceptance of Information Technology. MIS Quarterly, 13(3), 319. https://doi.org/10.2307/249008

Davis, F., Bagozzi, R., \& Warshaw, P. (1989). User Acceptance Of Computer Technology: A Comparison Of Two Theoretical Models. Management Science, 35(8), 982. https:// doi.org/10.2307/2632151

Ghozali, I. (2014). Partial Least Squares Konsep, Teknik dan Aplikasi Menggunakan Program Smartpls 3.0, (Ml), 290.

Hanggono, A. A., Handayani, S. R., \& Susilo, H. (2015). Analisis atas Praktek TAM (Technology Acceptance Model) dalam Medukung Bisnis Online dengan Memanfaatkan Jejaring Sosial Instagram. Jurnal Administrasi Bisnis, 26(1), 1-9. https://doi.org/administrasibisnis.studentjournal.ub.ac.id.

Kartika. (2013). Technology Acceptence Model: Menguji Keefektivan Penerimaan Sistem Informasi Terpadu (Sister) di Lingkungan Universitas Jember. Jurnal Akuntansi Fakultas Ekonomi Universitas Jember, (November), 127.

Kartika, S. E. (2009). Analisis Proses Penerimaan Sistem Informasi iCons dengan Menggunakan Technology Acceptance Model pada Karyawan PT. Bank Negara Indonesia (PERSERO) TBK di Kota Semarang.

Latifah, \& Afifah, A. N. (2013). Pengaruh Variabel Perceived Usefulness, Perceived Ease of Use , Perceived Enjoyment dan Attitude terhadap Pemanfaatan Visual Hotel Program pada Hotel-Hotel di Yogyakarta. Jurnal Riset Akuntansi \& Komputerisasi Akuntansi, 4(1), 33-47.

Lewis, W., Agarwal, R., \& Sambamurthy, V. (2003). Sources of influence on beliefs about information technology use: An empirical study of knowledge workers. , 657-678. MIS Quarterly, 27(4), 657-678. https://doi.org/10.1017/CBO9781107415324.004

Muntianah, S. T., Astuti, E. S., \& Azizah, D. F. (2012). Pengaruh Minat Perilaku Terhadap Actual Use Teknologi Informasi dengan Pendekatan Technology Acceptance Model (TAM). Profit Universitas Brawijaya Malang, 6(1), 88-113.

Myristika, N. (2014). Analisis Penerimaan Mahasiswa terhadap Sistem Informasi Akademik Berbasis Web di Universitas Brawijaya dengan Menggunakan Technology Acceptance Model (TAM). Jurnal Ilmiah Mahasiswa FEB Universitas Brawijaya, 2.

Nugraha, A., \& Laksito, H. (2014). Anteseden Penerimaan Teknologi Informasi dalam Profesi Audit Internal dengan Menggunakan Technology Acceptance Model (Studi Empiris pada Bank Perkreditan Rakyat di Jawa Tengah). Diponegoro Journal of Accounting, 3(2), 185-199.

Paramita, A. V., \& Mudjahidin. (2014). Analisis Kemanfaatan dan Kemudahan Penggunaan Aplikasi Manajemen Surat dengan Pendekatan Technology Acceptance Model pada PT. XYZ Surabaya. Jurnal Teknik POMITS, 3(2), 216-221. 
Primawati, A. (2015). Kajian Kesiapan dan Penerimaan Teknologi Aplikasi Google Documents untuk Penyelesaian Tugas Kelompok Siswa: Studi Kasus pada SMA Mardi Waluya Cibinong. Seminar Nasional Cendikiawan, 1-11.

Santoso, W., \& Setiawan, D. (2017). Faktor-Faktor Yang Mempengaruhi Niat Penggunaan Approweb Oleh Account Representative Direktorat Jenderal Pajak. Ecojoin.Org, XXI(02), 232-252. Retrieved from http://www.ecojoin.org/index.php/EJA/article/view/197

Sarastini, N. P. E., \& Suardikha, I. M. S. (2017). Pengaruh Pelatihan dan Pendidikan, Dukungan Manajemen Puncak dan Kemampuan Teknik Pemakai Sia Pada Kinerja Individual. E-Jurnal Akuntansi Universitas Udayana, 20(2), 1476-1503. https://doi.org/https://doi.org/10.24843/EJA.2017.v20.i02.p22

Sari, E. N. (2016). Analisis Faktor dalam Menggunakan Layanan E-BILL Dengan Pendekatan Technology Acceptance Model ( TAM ). Jurnal Ilmu Dan Riset Akuntansi, 5(April), 1-23.

Sidharta, I., \& Rahmahwati, S. (2014). Pengukuran Persepsi Manfaat dan Persepsi Kemudahan Terhadap Sikap serta Dampaknya atas Penggunaan Ulang Online Shopping pada E-Commerce. Jurnal Computech $\mathcal{E}$ Bisnis, $8(2), 92-100$.

Suardikha, I. M. S., T., S., Sukoharsono, E. G., \& Purnomosidhi, B. (2012). Pengaruh Implementasi Budaya Tri Hita Karana Terhadap Penggunaan Sistem Informasi Akuntansi Dimediasi Keyakinan-Diri Atas Komputer, Keinovatifan Personal, Persepsi Kegunaan, Dan Persepsi Kemudahan Penggunaan Pada Bank Perkreditan Rakyat Di Bali. SNA XV Universitas Lambung Mangkurat Banjarmasin, 1-45.

Sulistyarini, S. (2012). Pengaruh Minat Individu terhadap Penggunaan Mobile Banking: Model Kombinasi Technology Acceptance Model (TAM) dan Theory of Planned Behavior (TPB). Jurnal Universitas Brawijaya, $1-20$.

Sullivan, L. O., Power, V., Ortiz, J., \& Italiano, I. (2017). User Centered Design and Usability of Bionic, (October). https://doi.org/10.1007/978-3319-46669-9

Taylor, S., \& Todd, P. A. (1995). Understanding Information Technology Usage: A Test of Competing Models. Information System Research, 6(2).

Utama, A. (2012). Pengaruh Faktor Institusional, Sosial Serta Individu terhadap Persepsi Manfaat Menggunakan Teknologi Informasi. Jurnal Manajemen Universitas Negeri Yogyakarta.

Utama, A., Wibowo, A., \& Nurhadi. (2014). Pengaruh Faktor Individu Terhadap Keyakinan Manfaat Menggunakan Teknologi Informasi. Jurnal Economia Universitas Negeri Yogyakarta, 10(2), 177-186. 